\title{
FAKTOR-FAKTOR YANG MEMENGARUHI PEMAKAIAN ALAT METODE KONTRASEPSI JANGKA PANJANG PADA ISTRI PASANGAN USIA SUBUR (PUS) DI PUSKESMAS PANCUR BATU KABUPATEN DELI SERDANG TAHUN 2017
}

\author{
Honglianta R. Saragih \\ UPT Pelatihan Kesehatan SU \\ email : natassalaora@yahoo.co.id
}

\begin{abstract}
Abstrak
Metode Kontrasepsi Jangka Panjang (MKJP) adalah alat kontrasepsi yang digunakan untuk menunda kehamilan. Puskesmas Pancur Batu Kabupaten Deli Serdang memiliki jumlah penduduk terbanyak yaitu 1.895 jiwa, dengan jumlah PUS 322 orang, dan peserta KB aktif 244 orang, jumlah pengguna MKJP 56 orang dan non MKJP 188 orang. Tujuan penelitian adalah mengetahui faktor-faktor yang mempengaruhi pemakaian alat MKJP pada isteri PUS di Puskesmas Pancur Batu Kabupaten Deli Serdang Tahun 2017. Populasi adalah ibu PUS yang menggunakan alat kontrasepsi sebanyak 244 orang. Teknik pengambilan sampel menggunakan metode systematic random sampling yaitu 71 orang. Hasil penelitian bahwa dari 71 responden, jumlah mayoritas umur $>36$ tahun 49 orang $(69,0 \%)$, pendidikan menengah 40 orang $(56,3 \%)$, paritas $>2$ orang adalah 50 orang $(70,4 \%)$, pengetahuan kurang 46 orang $(64,8 \%)$, sikap negatif 46 orang $(64,8 \%)$, persepsi nilai anak baik 36 orang $(50,7 \%)$, KIE (Komunikasi Informasi dan Edukasi) kategori baik 50 orang $(70,4 \%)$, suami tidak mendukung 41 orang $(57,7 \%)$ dan tidak menggunakan MKJP 40 orang $(56,3 \%)$. Kesimpulan adanya pengaruh faktor predisposisi (umur, pendidikan, paritas, pengetahuan, sikap, persepsi nilai anak), pemungkin (KIE) dan pendorong (dukungan suami) terhadap pemakaian alat MKJP pada istri PUS. Disarankan bagi PUS lebih mencari informasi tentang kontrasepsi jangka panjang dan konsultasi kepada tenaga kesehatan terdekat, karena MKJP merupakan metode yang sangat efektif bagi PUS yang memiliki anak lebih dari 2 anak.
\end{abstract}

Kata Kunci : Pemakaian, Alat Metode Kontrasepsi Jangka Panjang, Isteri PUS

\section{PENDAHULUAN}

Metode Kontrasepsi Jangka Panjang (MKJP) adalah alat kontrasepsi yang digunakan untuk menunda kehamilan, serta menghentikan kesuburan yang digunakan dengan jangka panjang yang meliputi AKDR (Alat Kontrasepsi Dalam Rahim)/IUD (Intra Uterine Device), implant, MOW (Metode Operasi Wanita), MOP (Metode Operasi Pria). Metode kontrasepsi jangka panjang bertujuan agar terwujudnya kesejahteraan masyarakat Indonesia (Sarwono, 2014)

Salah satu target MDGs adalah akses universal terhadap pelayanan kesehatan reproduksi yang salah satu indikatornya adalah peningkatan angka prevalensi pemakaian kontrasepsi (CPR), yang didefinisikan sebagai penggunaan kontrasepsi saat ini (metode apapun) di antara perempuan menikah usia 15-49 tahun. Negara-negara di bagian timur dan timur laut Asia (dengan data yang tersedia) memiliki CPR di atas 50\%. Berdasarkan data tahun terbaru yang tersedia di setiap negara, CPR terendah terdapat di Afghanistan (23\%, 2008), Pakistan (27\%, 2008), Samoa $(29 \%, 2009)$ dan Timor-Leste $(22 \%, 2010)$ (UNESCAP, 2011)
Prevalensi pemakaian kontrasepsi jangka panjang khususnya MOW dan IUD cukup tinggi, masing masing $33,7 \%$ dan $25,6 \%$, dibandingkan MOP $(4,2 \%)$ dan Implat (1\%). Dalam 3 dekade terakhir MOW mencakup sepertiga dari metode kontrasepsi modern yang di pakai di Asia (yang terbanayak di India dan Cina) dan Amerika latin, juga merupakan metode kontrasepsi terbanyak di Amerika Utara. Data terakhir prevalensi MOW di Asia (39\%), Amerika latin (38\%), Amerika Utara (32\%0, Oseania (24\%), dan di Asia, di Eropa 1 dari 5 wanita yang memakai KB modern memilih IUD di Asia (29\%0, Eropa (21\%), Afrika (19\%), Amerika Latin (11\%), Amerika Utara (7\% dan Oseania (2\%) (BKKBN, 2012)

Riskesdas 2015 persentase peserta KB aktif menurut metode kontrasepsi MKJP sebanyak (10,9\%) sedangkan metode kontrasepsi NON MKJP sebanyak (34,5\%). Metode kontrasepsi yang paling digunakan oleh peserta KB aktif adalah suntikan (46,87\%) dan terbanyak ke dua adalah pil $(24,54 \%)$ dan kondom sebanyak $3,22 \%$ metode kontrasepsi yang paling sedikit dipilih oleh peserta KB aktif adalah Metoda Operasi Pria (MOP), yakni sebanyak $0,69 \%$, dan MOW sebanyak 3,52\%, Implan sebanyak 9,75\%, IUD sebanyak 11,41\% (Rikesdas, 2015) 
Peserta Baru KB menurut Metode Kontrasepsi di Indonesia, Tahun 2016 untuk Akseptor KB Intra Uterine Device (IUD) $(7,75 \%)$, Metode Operasi Wanita (MOW) $(1,52 \%)$, Metode Operasi Pria (MOP) $(0,25 \%)$, Kondom $(6,09 \%)$, Implan (9,23\%), suntikan (48,56\%), pil (26,60\%). Data Badan Kependudukan dan Keluarga Berencana Nasional (BKKBN) menunjukkan bahwa pada tahun 2016 ada 8.500.247 PUS (Pasangan Usia Subur) yang merupakan peserta $\mathrm{KB}$ baru, dan hampir separuhnya $(48,56 \%)$ menggunakan metode kontrasepsi suntikan (BKKBN, 2016)

Hasil survei pendahuluan pada bulan April tahun 2017 yang dilakukan di Puskesmas Pancur Batu Kabupaten Deli Serdang, dari 20 orang ibu PUS ditemukan sebanyak 13 orang $(65 \%)$ bukan merupakan akseptor KB dan 7 orang (35\%) yang akseptor KB. Memakai kondom 1 orang (5\%), implant 3 orang (15\%) dan MOW 3 orang $(15 \%)$. Dari 6 orang memakai MKJP, 5 orang $(43 \%)$ berusia $>30$ tahun dan 1 orang $(17 \%)$ berusia $<30$ tahun. Ketika ditanya pengetahuannya tentang MKJP ternyata banyak yang tidak tahu sebanyak 12 orang $(60,0 \%)$. Beberapa alasan tidak menggunakan alat KB, Khususnya MKJP antara lain suami/keluarga tidak mendukung (30\%), takut terhadap efek samping alat KB $(20,0 \%)$, anak adalah pemberian Tuhan sehingga tidak boleh dibatasi jumlahnya $(15,0 \%)$ dan belum mempunyai anak laki- laki/ perempuan $(15 \%)$. Berdasarkan hal di atas maka peneliti tertarik untuk meneliti faktor-faktor yang memengaruhi pemakaian alat metode kontrasepsi jangka panjang pada istri PUS di Puskesmas Pancur Batu Kabupaten Deli Serdang Tahun 2017.

\section{Rumusan Masalah}

Berdasarkan uraian diatas maka rumusan masalah penelitian ini adalah:

a. Bagaimana pemakaian alat metode kontrasepsi jangka panjang pada isteri PUS di Puskesmas Pancur Batu Kabupaten Deli Serdang Tahun 2017 ?

b. Apa faktor-faktor yang memengaruhi pemakaian alat metode kontrasepsi jangka panjang pada isteri PUS di Puskesmas Pancur Batu Kabupaten Deli Serdang Tahun 2017 ?

c. Apa faktor yang dominan memengaruhi pemakaian alat metode kontrasepsi jangka panjang pada isteri PUS di Puskesmas Pancur Batu Kabupaten Deli Serdang Tahun 2017 ?

\section{Tujuan}

a. Untuk mengetahui distribusi frekuensi pemakaian alat metode kontrasepsi jangka panjang pada istri PUS di Puskesmas Pancur Batu Kabupaten Deli Serdang Tahun 2017.

b. Untuk mengetahui faktor predisposisi (umur, pendidikan, paritas, pengetahuan, sikap, persepsi nilai anak), faktor pemungkin (KIE) dan faktor pendorong (dukungan suami) yang berhubungan dengan pemakaian alat metode kontrasepsi jangka panjang pada istri PUS di Puskesmas
Pancur Batu Kabupaten Deli Serdang Tahun 2017.

c. Mengetahui faktor dominan yang berhubungan dengan pemakaian alat metode kontrasepsi jangka panjang pada istri PUS di Puskesmas Pancur Batu Kabupaten Deli Serdang Tahun 2017.

\section{METODE}

Penelitian ini menggunakan metode survei analitik dengan pendekatan cross sectional. Penelitian dilakukan dengan tujuan untuk mengetahui faktor-faktor yang memengaruhi pemakaian alat metode kontrasepsi jangka panjang pada isteri PUS di Puskesmas Pancur Batu Kabupaten Deli Serdang Tahun 2017. Waktu penelitian ini dilakukan adalah April sampai Oktober 2017. Populasi penelitian adalah semua ibu pasangan usia subur yang menggunakan alat kontrasepsi yang bertempat tinggal di Puskesmas Pancur Batu Kabupaten Deli Serdang sebanyak 244 Ibu PUS. Teknik pengambilan sampel adalah dengan menggunakan rumus Slovin dalam Notoatmodjo (2010). ${ }^{8}$ Jadi, besar sampel yang diambil 71 orang. Pengambilan sampel diambil dengan cara acak sederhana (simple random sampling).

Aspek pengukuran menggunakan variabel Dependen dan Independen

\begin{tabular}{|c|c|c|c|c|c|}
\hline No & $\begin{array}{c}\text { Nama } \\
\text { Variabel }\end{array}$ & $\begin{array}{c}\text { Cara dan } \\
\text { Alat Ukur }\end{array}$ & $\begin{array}{c}\text { Skala } \\
\text { Pengukuran }\end{array}$ & Kategori & $\begin{array}{l}\text { Jenis } \\
\text { Skala } \\
\text { Ukur }\end{array}$ \\
\hline 1 & Umur & $\begin{array}{c}\text { Kuesioner } \\
1 \\
\text { pertanyaan }\end{array}$ & $\begin{array}{l}0 .<35 \text { tahun } \\
1 .>36 \text { tahun }\end{array}$ & $\begin{array}{l}0 \\
1\end{array}$ & Ordina \\
\hline 2 & Pendidikan & $\begin{array}{c}\text { Kuesioner } \\
1 \\
\text { pertanyaan }\end{array}$ & $\begin{array}{l}\text { 0. Menengah } \\
\text { 1. Tinggi }\end{array}$ & $\begin{array}{l}0 \\
1\end{array}$ & Ordina \\
\hline 3 & Paritas & $\begin{array}{c}\text { Kuesioner } \\
1 \\
\text { pertanyaan }\end{array}$ & $\begin{array}{l}0 . \leq 2 \text { orang } \\
1 .>2 \text { orang }\end{array}$ & $\begin{array}{l}0 \\
1\end{array}$ & Ordina \\
\hline 4 & Pengetahuan & $\begin{array}{c}\text { Kuesioner } \\
10 \\
\text { pertanyaan }\end{array}$ & $\begin{array}{l}\text { 0. Kurang } \\
\text { 1. Baik }\end{array}$ & $\begin{array}{l}0 \\
1\end{array}$ & Ordinal \\
\hline 5 & Sikap & $\begin{array}{c}\text { Kuesioner } \\
10 \\
\text { pernyataan }\end{array}$ & $\begin{array}{l}\text { 0. Negatif } \\
\text { 1. Positif }\end{array}$ & $\begin{array}{l}0 \\
1\end{array}$ & Ordinal \\
\hline 6 & $\begin{array}{l}\text { Persepsi Nilai } \\
\text { Anak }\end{array}$ & $\begin{array}{c}\text { Kuesioner } \\
9 \\
\text { pernyataan }\end{array}$ & $\begin{array}{l}\text { 0. Tidak baik } \\
\text { 1. Baik }\end{array}$ & $\begin{array}{l}0 \\
1\end{array}$ & Ordinal \\
\hline 7 & KIE & $\begin{array}{c}\text { Kuesioner } \\
6 \\
\text { pernyataan }\end{array}$ & $\begin{array}{l}\text { 0. Tidak baik } \\
\text { 1. Baik }\end{array}$ & $\begin{array}{l}0 \\
1\end{array}$ & Ordinal \\
\hline 8 & $\begin{array}{l}\text { Dukungan } \\
\text { suami }\end{array}$ & $\begin{array}{c}\text { Kuesioner } \\
8 \\
\text { pernyataan }\end{array}$ & $\begin{array}{l}\text { 0. Tidak } \\
\text { mendukung } \\
\text { 1. Mendukung }\end{array}$ & $\begin{array}{l}0 \\
1\end{array}$ & Ordinal \\
\hline 9 & $\begin{array}{l}\text { Pemakaian } \\
\text { metode } \\
\text { kontrasepsi } \\
\text { jangka } \\
\text { panjang }\end{array}$ & $\begin{array}{c}\text { Kuesioner } \\
1 \\
\text { pertanyaan }\end{array}$ & $\begin{array}{l}\text { 0. Tidak } \\
\text { menggunakan } \\
\text { MKJP } \\
\text { 1. Menggunakan } \\
\text { MKJP }\end{array}$ & 0 & Ordinal \\
\hline
\end{tabular}

Analisa data menggunakan :

\section{a. Analisa Univariat}

Analisis Univariat, yaitu analisis yang menggambarkan secara tunggal antar variabel baik variabel independen maupun dependen dalam bentuk distribusi frekuensi. 


\section{b. Analisa Bivariat}

Analisis bivariat yaitu analisis yang dilakukan untuk mengetahui adanya hubungan antara variabel independen dengan variabel dependen dengan menggunakan uji Chi-Squre pada tingkat kepercayaan $95 \%(\mathrm{p}<0,05)$

\section{c. Analisis Multivariat}

Analisis multivariat yaitu analisis lanjutan yang memungkinkan dilakukan untuk mengetahui variabel independen yang paling dominan berpengaruh dengan variabel dependen. Bila hasil uji mempunyai nilai $p<0.25$ maka variabel tersebut dapat masuk dalam model multivariat dengan menggunakan Uji Regresi Logistik Berganda (multiple logistic regression).

\section{HASIL}

1. Pengaruh Umur Terhadap Pemakaian Alat Metode Kontrasepsi Jangka Panjang Pada Istri PUS

Tabel. 1. Tabulasi Silang Pengaruh Umur Terhadap Pemakaian Alat Metode Kontrasepsi Jangka Panjang Pada Istri PUS di Puskesmas Pancur Batu Kabupaten Deli Serdang Tahun 2017

\begin{tabular}{|c|c|c|c|c|c|c|c|c|}
\hline \multirow{3}{*}{ No } & \multirow{3}{*}{ Umur } & \multicolumn{6}{|c|}{$\begin{array}{c}\text { Pemakaian Alat Metode Kontrasepsi Jangka } \\
\text { Panjang Pada Istri PUS } \\
\end{array}$} & \multirow[t]{2}{*}{$P$ value } \\
\hline & & \multicolumn{2}{|c|}{$\begin{array}{c}\text { Tidak } \\
\text { menggunakan } \\
\text { MKJP } \\
\end{array}$} & \multicolumn{2}{|c|}{$\begin{array}{l}\text { Menggunakan } \\
\text { MKJP }\end{array}$} & \multicolumn{2}{|c|}{ Total } & \\
\hline & & f & $\%$ & f & $\%$ & f & $\%$ & 0,001 \\
\hline 1 & $\begin{array}{l}<35 \\
\text { tahun }\end{array}$ & 19 & 26,8 & 3 & 4,2 & 22 & 31,0 & \\
\hline 2 & $\begin{array}{l}>\quad 36 \\
\text { tahun }\end{array}$ & 21 & 29,6 & 28 & 39,4 & 49 & 69,0 & \\
\hline & Jumlah & 40 & 56,3 & 31 & 43,7 & 71 & 100 & \\
\hline
\end{tabular}

Berdasarkan Tabel 1. bahwa umur responden kategori < 35 tahun yaitu 22 orang $(31,0 \%)$ yang memengaruhi pemakaian alat metode kontrasepsi jangka panjang pada istri PUS kategori tidak menggunakan MKJP yaitu 19 orang $(26,8 \%)$ dan menggunakan MKJP yaitu 3 orang $(4,2 \%)$ sedangkan umur responden kategori > 36 tahun yaitu 49 orang $(69,0 \%)$ yang memengaruhi pemakaian alat metode kontrasepsi jangka panjang pada istri PUS kategori tidak menggunakan MKJP yaitu 21 orang $(29,6 \%)$ dan menggunakan MKJP yaitu 28 orang $(39,4 \%)$. Berdasarkan hasil uji chi square diperoleh nilai PR 8,444, Cl 2,205-32,336; $p=0,001<\mathrm{p}=0,05$ artinya ada pengaruh umur terhadap pemakaian alat metode kontrasepsi jangka panjang pada istri PUS di Puskesmas Pancur Batu Kabupaten Deli Serdang tahun 2017
2. Pengaruh Pendidikan Terhadap Pemakaian Alat Metode Kontrasepsi Jangka Panjang Pada Istri PUS

Tabel 2. Tabulasi Silang Pengaruh Pendidikan Terhadap Pemakaian Alat Metode Kontrasepsi Jangka Panjang Pada Istri PUS di Puskesmas Pancur Batu Kabupaten Deli Serdang Tahun 2017

\begin{tabular}{|c|c|c|c|c|c|c|c|c|}
\hline \multirow{3}{*}{ No } & \multirow{3}{*}{ Pendidikan } & \multicolumn{6}{|c|}{$\begin{array}{c}\text { Pemakaian Alat Metode Kontrasepsi } \\
\text { Jangka Panjang Pada Istri PUS }\end{array}$} & \multirow[t]{2}{*}{$\begin{array}{c}P \\
\text { value }\end{array}$} \\
\hline & & \multicolumn{2}{|c|}{$\begin{array}{c}\text { Tidak } \\
\text { menggunakan } \\
\text { MKJP }\end{array}$} & \multicolumn{2}{|c|}{$\begin{array}{c}\text { Menggunakan } \\
\text { MKJP }\end{array}$} & \multicolumn{2}{|c|}{ Total } & \\
\hline & & $\mathbf{f}$ & $\%$ & $\mathbf{f}$ & $\%$ & f & $\%$ & 0,003 \\
\hline 1 & Menengah & 29 & 40,8 & 11 & 15,5 & 40 & 56,3 & \\
\hline 2 & Tinggi & 11 & 15,5 & 20 & 28,2 & 31 & 43,7 & \\
\hline & Jumlah & 40 & 56,3 & 31 & 43,7 & 71 & 100 & \\
\hline
\end{tabular}

Berdasarkan Tabel 2. bahwa pendidikan responden kategori menengah yaitu 40 orang $(56,3 \%)$ yang memengaruhi pemakaian alat metode kontrasepsi jangka panjang pada istri PUS kategori tidak menggunakan MKJP yaitu 29 orang $(40,8 \%)$ dan menggunakan MKJP yaitu 11 orang $(15,5 \%)$ sedangkan pendidikan responden kategori tinggi yaitu 31 orang $(43,7 \%)$ yang memengaruhi pemakaian alat metode kontrasepsi jangka panjang pada istri PUS kategori tidak menggunakan MKJP yaitu 11 orang $(15,5 \%)$ dan menggunakan MKJP yaitu 20 orang $(28,2 \%)$. Berdasarkan hasil uji chi square diperoleh nilai PR 4,793, Cl 1,743-13,180; $p=0,003<\mathrm{p}=0,05$ artinya ada pengaruh pendidikan terhadap pemakaian alat metode kontrasepsi jangka panjang pada istri PUS di Puskesmas Pancur Batu Kabupaten Deli Serdang tahun 2017.

3. Pengaruh Paritas Terhadap Pemakaian Alat Metode Kontrasepsi Jangka Panjang Pada Istri PUS

Tabel 3.Tabulasi Silang Pengaruh Paritas Terhadap Pemakaian Alat Metode Kontrasepsi Jangka Panjang Pada Istri PUS di Puskesmas Pancur Batu Kabupaten Deli Serdang Tahun 2017

Pemakaian Alat Metode Kontrasepsi Jangka $P$ value Panjang Pada Istri PUS

No Paritas Tidak Menggunakan Total

\begin{tabular}{|c|c|c|c|c|c|c|c|c|c|}
\hline & \multicolumn{2}{|c|}{$\begin{array}{c}\text { menggunakan } \\
\text { MKJP }\end{array}$} & \multicolumn{2}{|c|}{ MKJP } & \multirow[b]{2}{*}{$\mathbf{f}$} & \multirow[b]{2}{*}{$\%$} & \multirow[b]{2}{*}{0,001} \\
\hline & & & $\mathbf{f}$ & $\%$ & $\mathbf{f}$ & $\%$ & & & \\
\hline 1 & $\begin{array}{l}\leq 2 \\
\text { orang }\end{array}$ & & 18 & 25,4 & 3 & 4,2 & 21 & 29,6 & \\
\hline 2 & $\begin{array}{l}> \\
\text { orang }\end{array}$ & 2 & 22 & 31,0 & 28 & 39,4 & 50 & 70,4 & \\
\hline & Jumlah & & 40 & 56,3 & 31 & 43,7 & 71 & 100 & \\
\hline
\end{tabular}

Berdasarkan Tabel 3. bahwa paritas responden kategori $\leq 2$ orang yaitu 21 orang $(29,6 \%)$ yang memengaruhi pemakaian alat metode kontrasepsi jangka panjang pada istri PUS kategori tidak menggunakan MKJP yaitu 18 orang $(25,4 \%)$ dan menggunakan MKJP yaitu 3 orang $(4,2 \%)$ sedangkan paritas responden kategori $>2$ orang yaitu 50 orang $(70,4 \%)$ yang memengaruhi pemakaian alat metode kontrasepsi jangka panjang pada istri PUS kategori tidak menggunakan MKJP yaitu 22 orang $(31,0 \%)$ dan menggunakan MKJP yaitu 28 orang 
$(39,4 \%)$. Berdasarkan hasil uji chi square diperoleh nilai PR 7,636, Cl 1,992-29,274; $p=0,001<\mathrm{p}=0,05$ artinya ada pengaruh paritas terhadap pemakaian alat metode kontrasepsi jangka panjang pada istri PUS di Puskesmas Pancur Batu Kabupaten Deli Serdang tahun 2017.

4. Pengaruh Pengetahuan Terhadap Pemakaian Alat Metode Kontrasepsi Jangka Panjang Pada Istri PUS

Tabel 4. Tabulasi Silang Pengaruh Pengetahuan Terhadap Pemakaian Alat Metode Kontrasepsi Jangka Panjang Pada Istri PUS di Puskesmas Pancur Batu Kabupaten Deli Serdang Tahun 2017

\begin{tabular}{|c|c|c|c|c|c|c|c|c|}
\hline \multirow{3}{*}{ No } & \multirow{3}{*}{ Pengetahuan } & \multicolumn{6}{|c|}{$\begin{array}{c}\text { Pemakaian Alat Metode Kontrasepsi } \\
\text { Jangka Panjang Pada Istri PUS }\end{array}$} & \multirow[t]{2}{*}{ P value } \\
\hline & & \multicolumn{2}{|c|}{$\begin{array}{c}\text { Tidak } \\
\text { menggunakan } \\
\text { MKJP }\end{array}$} & \multicolumn{2}{|c|}{$\begin{array}{l}\text { Menggunakan } \\
\text { MKJP }\end{array}$} & \multicolumn{2}{|c|}{ Total } & \\
\hline & & $\mathbf{f}$ & $\%$ & f & $\%$ & f & $\%$ & 0,003 \\
\hline 1 & Kurang & 32 & 45,1 & 14 & 19,7 & 46 & 64,8 & \\
\hline \multirow[t]{2}{*}{2} & Baik & 8 & 11,3 & 17 & 23,9 & 25 & 35,2 & \\
\hline & Jumlah & 40 & 56,3 & 31 & 43,7 & 71 & 100 & \\
\hline
\end{tabular}

Berdasarkan Tabel 4. bahwa pengetahuan responden kategori kurang yaitu 46 orang $(64,8 \%)$ yang memengaruhi pemakaian alat metode kontrasepsi jangka panjang pada istri PUS kategori tidak menggunakan MKJP yaitu 32 orang $(45,1 \%)$ dan menggunakan MKJP yaitu 14 orang $(19,7 \%)$ sedangkan pengetahuan responden kategori baik yaitu 25 orang $(35,2 \%)$ yang memengaruhi pemakaian alat metode kontrasepsi jangka panjang pada istri PUS kategori tidak menggunakan MKJP yaitu 8 orang $(11,3 \%)$ dan menggunakan MKJP yaitu 17 orang $(23,9 \%)$. Berdasarkan hasil uji chi square diperoleh nilai PR 4,857, $\mathrm{Cl} 1,701-13,867 ; p=0,003<\mathrm{p}=0,05$ artinya ada pengaruh pengetahuan terhadap pemakaian alat metode kontrasepsi jangka panjang pada istri PUS di Puskesmas Pancur Batu Kabupaten Deli Serdang tahun 2017.

5. Pengaruh Sikap Terhadap Pemakaian Alat Metode Kontrasepsi Jangka Panjang Pada Istri PUS

Tabel 5. Tabulasi Silang Pengaruh Sikap Terhadap Pemakaian Alat Metode Kontrasepsi Jangka Panjang Pada Istri PUS di Puskesmas Pancur Batu Kabupaten Deli Serdang Tahun 2017

\begin{tabular}{|c|c|c|c|c|c|c|c|c|}
\hline \multirow{3}{*}{ No } & \multirow{3}{*}{ Sikap } & \multicolumn{6}{|c|}{$\begin{array}{l}\text { Pemakaian Alat Metode Kontrasepsi } \\
\text { Jangka Panjang Pada Istri PUS }\end{array}$} & \multirow[t]{2}{*}{ P value } \\
\hline & & \multicolumn{2}{|c|}{$\begin{array}{c}\text { Tidak } \\
\text { menggunakan } \\
\text { MKJP } \\
\end{array}$} & \multicolumn{2}{|c|}{$\begin{array}{c}\text { Menggunakan } \\
\text { MKJP }\end{array}$} & \multicolumn{2}{|c|}{ Total } & \\
\hline & & f & $\%$ & f & $\%$ & f & $\%$ & 0,001 \\
\hline 1 & Negatif & 33 & 46,5 & 13 & 18,3 & 46 & 64,8 & \\
\hline \multirow[t]{2}{*}{2} & Positif & 7 & 9,9 & 18 & 25,4 & 25 & 35,2 & \\
\hline & Jumlah & 40 & 56,3 & 31 & 43,7 & 71 & 100 & \\
\hline
\end{tabular}

Berdasarkan Tabel 5. bahwa sikap responden kategori negatif yaitu 46 orang $(64,8 \%)$ yang memengaruhi pemakaian alat metode kontrasepsi jangka panjang pada istri PUS kategori tidak menggunakan MKJP yaitu 33 orang $(46,5 \%)$ dan menggunakan MKJP yaitu 13 orang $(18,3 \%)$ sedangkan sikap responden kategori positif yaitu
25 orang $(35,2 \%)$ yang memengaruhi pemakaian alat metode kontrasepsi jangka panjang pada istri PUS kategori tidak menggunakan MKJP yaitu 7 orang $(9,9 \%)$ dan menggunakan MKJP yaitu 18 orang $(25,4 \%)$. Berdasarkan hasil uji chi square diperoleh nilai $\mathrm{PR} 6,527, \mathrm{Cl} 2,209$ 19,290; $p=0,001<\mathrm{p}=0,05$ artinya ada pengaruh sikap terhadap pemakaian alat metode kontrasepsi jangka panjang pada istri PUS di Puskesmas Pancur Batu Kabupaten Deli Serdang tahun 2017

6. Pengaruh Persepsi Nilai Anak Terhadap Pemakaian Alat Metode Kontrasepsi Jangka Panjang Pada Istri PUS

Tabel 6. Tabulasi Silang Pengaruh Persepsi Nilai Anak Terhadap Pemakaian Alat Metode Kontrasepsi Jangka Panjang Pada Istri PUS di Puskesmas Pancur Batu Kabupaten Deli Serdang Tahun 2017

\begin{tabular}{|c|c|c|c|c|c|c|c|c|}
\hline \multirow{3}{*}{ No } & \multirow{3}{*}{$\begin{array}{c}\text { Persepsi } \\
\text { Nilai } \\
\text { Anak }\end{array}$} & \multicolumn{6}{|c|}{$\begin{array}{l}\text { Pemakaian Alat Metode Kontrasepsi } \\
\text { Jangka Panjang Pada Istri PUS }\end{array}$} & \multirow[t]{2}{*}{ P value } \\
\hline & & \multicolumn{2}{|c|}{$\begin{array}{c}\text { Tidak } \\
\text { menggunakan } \\
\text { MKJP }\end{array}$} & \multicolumn{2}{|c|}{$\begin{array}{l}\text { Menggunakan } \\
\text { MKJP }\end{array}$} & \multicolumn{2}{|c|}{ Total } & \\
\hline & & f & $\%$ & f & $\%$ & f & $\%$ & 0,004 \\
\hline 1 & $\begin{array}{l}\text { Tidak } \\
\text { baik }\end{array}$ & 26 & 36,6 & 9 & 12,7 & 35 & 49,3 & \\
\hline 2 & Baik & 14 & 19,7 & 22 & 31,0 & 36 & 50,7 & \\
\hline & Jumlah & 40 & 56,3 & 31 & 43,7 & 71 & 100 & \\
\hline
\end{tabular}

Berdasarkan Tabel 6. bahwa persepsi nilai anak responden kategori tidak baik yaitu 35 orang $(49,3 \%)$ yang memengaruhi pemakaian alat metode kontrasepsi jangka panjang pada istri PUS kategori tidak menggunakan MKJP yaitu 26 orang $(36,6 \%)$ dan menggunakan MKJP yaitu 9 orang $(12,7 \%)$ sedangkan persepsi nilai anak responden kategori positif yaitu 36 orang (50,7\%) yang memengaruhi pemakaian alat metode kontrasepsi jangka panjang pada istri PUS kategori tidak menggunakan MKJP yaitu 14 orang $(19,7 \%)$ dan menggunakan MKJP yaitu 22 orang $(31,0 \%)$. Berdasarkan hasil uji chi square diperoleh nilai PR 4,540, Cl 1,651-12,486; $p=0,004<\mathrm{p}=0,05$ artinya ada pengaruh persepsi nilai anak terhadap pemakaian alat metode kontrasepsi jangka panjang pada istri PUS di Puskesmas Pancur Batu Kabupaten Deli Serdang tahun 2017

7. Pengaruh KIE (Komunikasi Informasi dan Edukasi) Terhadap Pemakaian Alat Metode Kontrasepsi Jangka Panjang Pada Istri PUS

Tabel 7. Tabulasi Silang Pengaruh KIE (Komunikasi Informasi dan Edukasi) Terhadap Pemakaian Alat Metode Kontrasepsi Jangka Panjang Pada Istri PUS di Puskesmas Pancur Batu Kabupaten Deli Serdang Tahun 2017

\begin{tabular}{|c|c|c|c|c|c|c|c|c|}
\hline \multirow{3}{*}{ No } & \multirow{3}{*}{$\begin{array}{c}\text { KIE } \\
\text { (Komunikasi } \\
\text { Informasi } \\
\text { dan } \\
\text { Edukasi) }\end{array}$} & \multicolumn{6}{|c|}{$\begin{array}{c}\text { Pemakaian Alat Metode Kontrasepsi } \\
\text { Jangka Panjang Pada Istri PUS }\end{array}$} & \multirow[t]{2}{*}{ P value } \\
\hline & & \multicolumn{2}{|c|}{$\begin{array}{c}\text { Tidak } \\
\text { menggunakan } \\
\text { MKJP }\end{array}$} & \multicolumn{2}{|c|}{$\begin{array}{l}\text { Menggunakan } \\
\text { MKJP }\end{array}$} & \multicolumn{2}{|c|}{ Total } & \\
\hline & & f & $\%$ & f & $\%$ & f & $\%$ & 0,000 \\
\hline 1 & Tidak baik & 19 & 26,8 & 2 & 2,8 & 21 & 29,6 & \\
\hline \multirow[t]{2}{*}{2} & Baik & 21 & 29,4 & 29 & 40,8 & 50 & 70,4 & \\
\hline & Jumlah & 40 & 56,3 & 31 & 43,7 & 71 & 100 & \\
\hline
\end{tabular}


Berdasarkan Tabel 7. bahwa KIE (Komunikasi Informasi dan Edukasi) responden kategori tidak baik yaitu 21 orang $(29,6 \%)$ yang memengaruhi pemakaian alat metode kontrasepsi jangka panjang pada istri PUS kategori tidak menggunakan MKJP yaitu 19 orang (26,8\%) dan menggunakan MKJP yaitu 2 orang $(2,8 \%)$ sedangkan KIE (Komunikasi Informasi dan Edukasi) responden kategori positif yaitu 50 orang $(70,4 \%)$ yang memengaruhi pemakaian alat metode kontrasepsi jangka panjang pada istri PUS kategori tidak menggunakan MKJP yaitu 21 orang $(29,4 \%)$ dan menggunakan MKJP yaitu 29 orang $(40,8 \%)$. Berdasarkan hasil uji chi square diperoleh nilai PR 13,119, Cl 2,753-65,525; $p=0,000<p=0,05$ artinya ada pengaruh KIE (Komunikasi Informasi dan Edukasi) terhadap pemakaian alat metode kontrasepsi jangka panjang pada istri PUS di Puskesmas Pancur Batu Kabupaten Deli Serdangtahun 2017

\section{Pengaruh Dukungan Suami Terhadap Pemakaian Alat Metode Kontrasepsi Jangka Panjang Pada Istri PUS}

Tabel 8. Tabulasi Silang Pengaruh Dukungan Suami Terhadap Pemakaian Alat Metode Kontrasepsi Jangka Panjang Pada Istri PUS di Puskesmas Pancur Batu Kabupaten Deli Serdang Tahun 2017

\begin{tabular}{|c|c|c|c|c|c|c|c|c|}
\hline \multirow{3}{*}{ No } & \multirow{3}{*}{$\begin{array}{l}\text { Dukungan } \\
\text { Suami }\end{array}$} & \multicolumn{6}{|c|}{$\begin{array}{c}\text { Pemakaian Alat Metode Kontrasepsi } \\
\text { Jangka Panjang Pada Istri PUS }\end{array}$} & \multirow[t]{2}{*}{$\begin{array}{c}\mathbf{P} \\
\text { value }\end{array}$} \\
\hline & & \multicolumn{2}{|c|}{$\begin{array}{c}\text { Tidak } \\
\text { menggunakan } \\
\text { MKJP } \\
\end{array}$} & \multicolumn{2}{|c|}{$\begin{array}{l}\text { Menggunakan } \\
\text { MKJP }\end{array}$} & \multicolumn{2}{|c|}{ Total } & \\
\hline & & $\mathbf{f}$ & $\%$ & f & $\%$ & $\mathbf{f}$ & $\%$ & 0,001 \\
\hline 1 & $\begin{array}{l}\text { Tidak } \\
\text { mendukung }\end{array}$ & 30 & 42,3 & 11 & 15,5 & 41 & 57,7 & \\
\hline \multirow[t]{2}{*}{2} & Mendukung & 10 & 14,1 & 20 & 28,2 & 30 & 42,3 & \\
\hline & Jumlah & 40 & 56,3 & 31 & 43,7 & 71 & 100 & \\
\hline
\end{tabular}

Berdasarkan Tabel 8. bahwa dukungan suami responden kategori tidak baik yaitu 41 orang $(57,7 \%$ ) yang memengaruhi pemakaian alat metode kontrasepsi jangka panjang pada istri PUS kategori tidak menggunakan MKJP yaitu 30 orang $(42,3 \%)$ dan menggunakan MKJP yaitu 11 orang $(15,5 \%)$ sedangkan dukungan suami responden kategori positif yaitu 30 orang $(42,3 \%)$ yang memengaruhi pemakaian alat metode kontrasepsi jangka panjang pada istri PUS kategori tidak menggunakan MKJP yaitu 10 orang $(14,1 \%)$ dan menggunakan MKJP yaitu 20 orang $(28,2 \%)$. Berdasarkan hasil uji chi square diperoleh nilai PR 5,455, Cl 1,954-15,224; $p=0,001<\mathrm{p}=0,05$ artinya ada pengaruh dukungan suami terhadap pemakaian alat metode kontrasepsi jangka panjang pada istri PUS di Puskesmas Pancur Batu Kabupaten Deli Serdang tahun 2017

Hasil uji regresi logistik menggunakan metode Backward Stepwise (Likelihood Ratio) diketahui bahwa indikator variabel faktor predisposisi (umur, pendidikan, paritas, pengetahuan, sikap, persepsi nilai anak), faktor pemungkin (KIE) dan faktor pendorong (dukungan suami) yang diuji seluruhnya berhubungan signifikan terhadap pemakaian alat metode kontrasepsi jangka panjang pada istri PUS $(\mathrm{p}<0,05)$. Dengan demikian hipotesis yang berbunyi "faktor predisposisi (umur, pendidikan, paritas, pengetahuan, sikap, persepsi nilai anak), faktor pemungkin
(KIE) dan faktor pendorong (dukungan suami) memengaruhi terhadap pemakaian alat metode kontrasepsi jangka panjang pada istri PUS di Puskesmas Pancur Batu Kabupaten Deli SerdangTahun 2017" diterima.

Hasil regresi logistik ganda model prediksi pada step 1 terhadap pemakaian alat metode kontrasepsi jangka panjang pada istri PUS di Puskesmas Pancur Batu Kabupaten Deli SerdangTahun 2017 diperoleh nilai pvalue $(\mathrm{sig})>0,05$ pada variabel umur $(0,116)$, pendidikan $(0,025)$, paritas $(0,379)$, pengetahuan $(0,745)$, sikap $(0,092)$, persepsi nilai anak $(0,226)$, KIE (Komunikasi Informasi Edukasi) $(0,184)$, dukungan suami $(0,010)$. Pada step ini variabel pengetahuan dikeluarkan dari pemodelan karena memiliki nilai probabilitas (p-value) tertinggi.

Kemudian pada step 2 diperoleh umur $(0,096)$, pendidikan $(0,020)$, paritas $(0,404)$, sikap $(0,045)$, persepsi nilai anak $(0,197)$, KIE (Komunikasi Informasi Edukasi) $(0,195)$, dukungan suami $(0,007)$. Pada step ini variabel paritas dikeluarkan dari pemodelan karena memliki nilai probabilitas ( $\mathrm{p}$-value) tertinggi

Pada step 3 diperoleh umur $(0,030)$, pendidikan $(0,012)$, sikap $(0,043)$, persepsi nilai anak $(0,087)$, KIE (Komunikasi Informasi Edukasi) $(0,244)$, dukungan suami $(0,007)$. Pada step ini variabel KIE (Komunikasi Informasi Edukasi) dikeluarkan dari pemodelan karena memiliki nilai probabilitas ( $\mathrm{p}$-value) tertinggi.

Selanjutnya pada step 4 diperoleh umur $(0,026)$, pendidikan $(0,007)$, sikap $(0,017)$, persepsi nilai anak $(0,016)$, dukungan suami $(0,008)$. Pada step ini variabel KIE (Komunikasi Informasi Edukasi) memengaruhi terhadap pemakaian alat metode kontrasepsi jangka panjang pada istri PUS. Variabel dominan pada step 4 memiliki pengaruh paling besar terhadap memengaruhi terhadap pemakaian alat metode kontrasepsi jangka panjang pada istri PUS adalah umur karena memiliki nilai koefisien regresi (B) yang paling besar yaitu 2,126 dengan nilai Exp (B) sebesar 8,384 artinya responden yang umur > 36 tahun terhadap pemakaian alat metode kontrasepsi jangka panjang pada istri PUS berpeluang 8,384 menggunakan MKJP dibandingkan dengan responden yang umur yang < 35 tahun dengan tidak menggunakan MKJP

\section{PEMBAHASAN}

1. Pengaruh Umur Terhadap Pemakaian Alat Metode Kontrasepsi Jangka Panjang Pada Istri PUS

Penelitian Anita tahun 2014 tentang faktor-faktor yang berhubungan dengan pemilihan kontrasepsi pasangan usia subur di Puskesmas Damau Kabupaten Talaud Manado menyatakan bahwa responden berumur > 30 tahun lebih banyak memilih Metode Kontrasepsi Jangka Panjang (17\%) dibandingkan dengan responden berumur $<20$ tahun tidak ada responden menggunakan Metode Kontrasepsi Jangka Panjang. hasil analisis statistik menunjukkan nilai $\rho=0.052(\rho<0,05)$ artinya ada hubungan antara umur dengan pemilihan kontrasepsi.

Penelitian Putri tahun 2015 menyatakan bahwa persentase yang paling besar adalah responden pengguna 
non MKJP berumur 20-30 tahun sebesar 33,3\%, sedangkan responden pengguna MKJP persentase lebih besar berumur $>30$ tahun sebesar 29,8\%. Uji logistik pengaruh umur responden dengan rendahnya keikutsertaan PUS menggunakan MKJP menunjukkan nilai $\mathrm{p}=0,005<$ $\alpha=0,05$ sehingga dapat disimpulkan bahwa terdapat pengaruh umur responden dengan rendahnya keikutsertaan PUS menggunakan MKJP.

Menurut peneliti bahwa ada pengaruh faktor umur terhadap pemakaian alat metode kontrasepsi jangka panjang pada istri PUS. Umur pada wanita subur berhubungan erat dengan penggunaan Metode Kontrasepsi Jangka Panjang umur dalam pengaruhnya dengan pemakaian KB berperan sebagai faktor instrinsik.

2. Pengaruh Pendidikan Terhadap Pemakaian Alat Metode Kontrasepsi Jangka Panjang Pada Istri PUS

Penelitian Nurul tahun 2016 menyatakan bahwa lebih dari setengah $(55,6 \%)$ sampel menggunakan kontrasepsi, sedangkan sisanya $(44,4 \%)$ tidak menggunakan kontrasepsi. Terdapat kecenderungan semakin tinggi usia wanita PUS dan semakin banyak paritas, maka akan semakin rendah penggunaan $\mathrm{KB}$. Terdapat pula kecenderungan responden yang bekerja lebih sedikit menggunakan KB. Semakin tinggi tingkat pendidikan wanita PUS, penghasilan keluarga, pengetahuan dan dukungan petugas, maka cenderung semakin tinggi penggunaan KB.

Penelitian Putri tahun 2016 menyatakan bahwa sebagian besar responden pengguna MKJP berpendidikan SMP dan responden pengguna MKJP sebagian besar berpendidikan SMA/PT. Dapat disimpulkan terdapat pengaruh tingkat pendidikan responden dengan rendahnya keikutsertaan PUS menggunakan MKJP yang dapat dilihat dari hasil uji logistik menunjukkan nilai $\mathrm{p}=0,015<\alpha=$ 0,05 .

Pendidikan berpengaruh pada penggunaan kontrasepsi. Wanita dengan pendidikan minimal menengah dan mendiskusikan keluarga berencana dengan pasangan mereka memiliki probabilitas tinggi menggunakan kontrasepsi dibandingkan dengan tidak memiliki pendidikan atau dengan pendidikan rendah. adanya perbedaan antara wanita yang berpendidikan tinggi dengan wanita yang tidak sekolah. Hasil menunjukan wanita dengan tingkat pendidikan lebih tinggi memiliki peluang yang lebih baik menggunakan yang metode kontrasepsi modern 4,8 kali daripada wanita yang pendidikan rendah atau tidak sekolah. Adanya perbedaan antara wanita yang berpendidikan tinggi dengan wanita yang tidak sekolah. Hasil menunjukan wanita dengan tingkat pendidikan lebih tinggi memiliki peluang yang lebih baik menggunakan yang metode kontrasepsi modern 4,8 kali daripada wanita yang pendidikan rendah atau tidak sekolah (Yunita, 2012)

Menurut peneliti bahwa ada pengaruh faktor pendidikan terhadap pemakaian alat metode kontrasepsi jangka panjang pada istri PUS. Pendidikan yang tinggi memengaruhi dalam proses penerimaan informasi, sehingga dalam proses penyampaian informasi tentang metode dari program $\mathrm{KB}$ diperlukan penyesuaian dengan tingkat pendidikan sasaran.

\section{Pengaruh Paritas Terhadap Pemakaian Alat Metode Kontrasepsi Jangka Panjang Pada Istri PUS}

Paritas atau jumlah anak adalah keseluruhan jumlah anak yang dilahirkan hidup oleh seorang ibu. Semakin sering seorang wanita melahirkan anak, maka akan semakin memiliki resiko kematian dalam persalinan. Hal ini berarti jumlah anak akan sangat mempengaruhi kesehatan ibu dan dapat meningkatkan taraf hidup keluarga secara maksimal. Pengguna KB dipengaruhi juga dengan jumlah anak dalam suatu keluarga. Pasangan usia subur 30 tahun keatas yang sudah memiliki anak dan ingin menjarangkan kehamilannya biasanya lebih cenderung memilih kontrasepsi jangka panjang (Sarwono, 2014)

Menurut peneliti bahwa ada pengaruh faktor paritas terhadap pemakaian alat metode kontrasepsi jangka panjang pada istri PUS. Jumlah anak hidup memengaruhi pasangan usia subur dalam menentukan metode kontrasepsi yang akan digunakan. Pada pasangan dengan jumlah anak hidup masih sedikit terdapat kecenderungan untuk menggunakan metode kontrasepsi dengan efektivitas rendah, sedangkan pada pasangan dengan jumlah anak hidup banyak terdapat kecenderungan menggunakan metode kontrasepsi dengan efektivitas tinggi seperti MKJP.

\section{Pengaruh Pengetahuan Terhadap Pemakaian Alat Metode Kontrasepsi Jangka Panjang Pada Istri PUS}

Pengetahuan PUS tentang alat kontrasepsi jangka panjang dalam kategori kurang baik karena kurangnya informasi yang diketahui oleh PUS tentang keuntungan dan kerugian metode kontrasepsi jangka panjang. Rendahnya pengetahuan masyarakat terutama PUS tentang alat kontrasepsi jangka panjang, dapat menjadi faktor predisposisi bagi PUS untuk tidak menggunakan alat kontrasepsi jangka panjang sebagai pilihan kontrasepsi yang efektif bagi pencegahan kehamilan dalam jangka panjang. Pengetahuan PUS tentang alat kontrasepsi jangka panjang sangat penting. Hal ini akan meningkatkan penggunaan kontrasepsi jangka panjang (Rosmadewi, 2015)

Menurut peneliti bahwa ada pengaruh faktor pengetahuan terhadap pemakaian alat metode kontrasepsi jangka panjang pada istri PUS. Tingkat pengetahuan masyarakat akan mempengaruhi penerimaan program $\mathrm{KB}$ di masyarakat. Pengetahuan yang benar tentang program KB termasuk tentang berbagai jenis kontrasepsi akan mempertinggi keikutsertaan masyarakat dalam program KB.

5. Pengaruh Sikap Terhadap Pemakaian Alat Metode Kontrasepsi Jangka Panjang Pada Istri PUS

Penelitian Wulandari tahun 2016 menyatakan bahwa sikap pasangan usia subur tentang kontrasepsi 
jangka panjang masih kurang dan sesudah diberikan konseling kontrasepsi nilai rata-rata responden mengenai sikap tentang kontrasepsi jangka panjang meningkat menjadi 48,65 yang menunjukkan bahwa sikap pasangan usia subur tentang alat kontrasepsi jangka panjang menjadi lebih baik dibandingkan sebelum diberikan konseling.

Menurut peneliti bahwa ada pengaruh faktor sikap terhadap pemakaian alat metode kontrasepsi jangka panjang pada istri PUS. Responden yang mempunyai sikap positif mengetahui tentang pemilihan alat kontrasepsi dalam pemakaian alat metode kontrasepsi jangka panjang pada istri PUS.

\section{Pengaruh Persepsi Nilai Anak Terhadap Pemakaian Alat Metode Kontrasepsi Jangka Panjang Pada Istri PUS}

Anak mempunyai nilai tertentu bagi orang tua, dan memiliki anak menuntut beberapa konsekuensi yang harus dipenuhi karenanya. Latar belakang sosial (tingkat pendidikan, kesehatan, adat/budaya, pekerjaan, tingkat penghasilan) yang berbeda menyebabkan pandangan yang berbeda mengenai anak. Di daerah pedesaan anak mempunyai nilai yang tinggi bagi keluarga. Anak dapat memberikan kebahagiaan kepada orang tuanya selain itu akan merupakan jaminan di hari tua dan dapat membantu ekonomi keluarga, banyak masyarakat di desa di Indonesia yang berpandangan bahwa banyak anak banyak rejeki (Sarwono, 2014)

Menurut peneliti bahwa ada pengaruh faktor persepsi nilai anak terhadap pemakaian alat metode kontrasepsi jangka panjang pada istri PUS. Responden yang memiliki persepsi nilai anak yang baik memiliki keyakinan bahwa anak memberi lebih banyak keuntungan daripada kerugian.

\section{Pengaruh KIE (Komunikasi Informasi dan \\ Edukasi) Terhadap Pemakaian Alat Metode Kontrasepsi Jangka Panjang Pada Istri PUS}

KIE (Komunikasi Informasi dan Edukasi) adalah suatu kegiatan dimana terjadi proses komunikasi dengan penyebaran informasi yang mempercepat tercapainya perubahan perilaku dari masyarakat. KIE sebagai salah satu komponen operasional yang strategis dalam program KB nasional mempunyai fungsi dan peranan penting guna meningkatkan dan memantapkan penerimaan masyarakat khususnya tentang $\mathrm{KB}$ dan kesehatan reproduksi (Saifuddin, 2013)

Menurut peneliti bahwa ada pengaruh faktor KIE (Komunikasi Informasi dan Edukasi) terhadap pemakaian alat metode kontrasepsi jangka panjang pada istri PUS. KIE sebagai salah satu komponen operasional yang strategis dalam program KB Nasional mempunyai fungsi dan peranan penting guna meningkatkan dan memantapkan penerimaan masyarakat akan program KB. Meningkatnya pengetahuan masyarakat/keluarga tentang kesehatan reproduksi dan $\mathrm{KB}$ akan mendorong perubahan sikap dan perilaku untuk penerimaan dan pemakaian metode kontrasepsi termasuk MKJP

\section{Pengaruh Dukungan Suami Terhadap Pemakaian Alat Metode Kontrasepsi Jangka Panjang Pada Istri PUS}

Pemakaian kontrasepsi termasuk kontrasepsi jangka panjang akan semakin baik jika ada dukungan dari pihakpihak tertentu. Ikatan suami istri yang kuat sangat membantu ketika keluarga menghadapi masalah, karena suami/isteri sangat membutuhkan dukungan dari pasangannya. Hal itu disebabkan orang yang paling bertanggung jawab terhadap keluarganya adalah pasangan itu sendiri. Di dalam masyarakat Indonesia khususnya yang tinggal di pedesaan, suamilah yang berperan sebagai penentu dalam pengambilan keputusan dalam keluarga, sedangkan isteri hanya memberikan sumbang saran (Sarwono, 2014)

Menurut peneliti bahwa ada pengaruh faktor dukungan suami terhadap pemakaian alat metode kontrasepsi jangka panjang pada istri PUS. Dukungan suami dalam penggunaan alat kontrasepsi MKJP sangat berpengaruh untuk medukung wanita pasangan usia subur dalam penggunaan MKJP. Dukungan keluarga merupakan bantuan yang dapat diberikan keluarga berupa barang, jasa, informasi dan nasehat yang mana membuat penerima dukungan akan merasa disayang, dihargai dan tentram.

\section{Simpulan}

a. Pemakaian alat MKJP pada istri PUS kategori tidak menggunakan MKJP yaitu 40 orang $(56,3 \%)$ dan menggunakan MKJP yaitu 31 orang $(43,7 \%)$.

b. Ada pengaruh faktor predisposisi (umur, pendidikan, paritas, pengetahuan, sikap, persepsi nilai anak), faktor pemungkin (KIE) dan faktor pendorong (dukungan suami) terhadap pemakaian alat MKJP pada istri PUS di Puskesmas Pancur Batu Kabupaten Deli Serdang tahun 2017

c. Variabel dominan memiliki pengaruh paling besar terhadap pemakaian alat MKJP pada istri PUS adalah umur

\section{Saran}

a. Bagi Pasangan Usia Subur

Disarankan memahami manfaat kontrasepsi jangka panjang dengan mengadakan konsultasi kepada tenaga kesehatan karena metode kontrasepsi jangka panjang merupakan metode yang sangat efektif bagi PUS yang memiliki anak lebih dari 2 anak

b. Bagi Petugas Kesehatan

Meningkatkan penyuluhan tentang kontrasepsi terutama MKJP kepada wanita pasangan usia subur dan juga kepada suami agar mereka mempunyai pengetahuan yang baik mengenai alat kontrasepsi tersebut yang diharapkan ketika mereka mempunyai pengetahuan yang cukup tentang alat kontrasepsi berjangka panjang, mereka dapat menentukan pilihan dan mampu mengatur dan mencegah kelahiran yang tidak diinginkan

c. Bagi Penelitian Selanjutnya

Dapat menjadi masukan bagi penelitian selanjutnya yang berkaitan dengan faktor-faktor yang memengaruhi pemakaian alat MKJP pada istri PUS 


\section{DAFTAR PUSTAKA}

Anita Lontaan. Faktor-Faktor Yang Berhubungan Dengan Pemilihan Kontrasepsi Pasangan Usia Subur di Puskesmas Damau Kabupaten Talaud Manado. 2014. [Jurnal Internet]. Tersedia dari journal.unnes.ac.id/artikel_sju/ujph/7222/5008. Diakses tanggal 7 November 2017

BKKBN. Kajian Implementasi Kebijakan Penggunaan MKJP Jakarta; 2012.

BKKBN. Profil Kesehatan Indonesia. Jakarta. 2016

Nurul Farahan. Gambaran Tingkat Pengetahuan Penggunaan Alat Kontrasepsi Pada Wanita Usia Subur dan Dukungan Petugas di Desa Bebandem Kabupaten Karangasem Bali. 2016. [Jurnal Internet. Tersedia dari https://ojs.unud.ac.id/index.php/eum/article/view/1 9960/13253. Diakses tanggal 17 September 2017

Putri Hariyani Chandra Dewi. Rendahnya Keikutsertaan Pengguna Metode Kontrasepsi Jangka Panjang Pada Pasangan Usia Subur. 2016. [Jurnal Internet. Tersedia dari download.portal garuda.org/article.php?...Rendahnya\%20

Keikutsertaan\%20Penggunaankontrasepsi. Diakses tanggal 16 September 2017

Riset Kesehatan Dasar. Laporan Nasional Riset Kesehatan Dasar, Jakarta. 2015

Rosmadewi. Hubungan Pengetahuan dan Tingkat Ekonomi Dengan Penggunaan Alat Kontrasepsi di Wilayah Puskesmas Sekampung Kabupaten Lampung Timur. 2015. . [Jurnal Internet. Tersedia dari poltekkes-tjk.ac.id/ejurnal/index.php/ JKM/ article/view/165/157. Diakses tanggal 1 Oktober 2017
Saifuddin, Abdul Bari. Buku Pedoman Praktis Pelayanan Kontrasepsi, Yayasan Bina Pustaka, Jakarta. 2013

Sarwono Prawirohardjo. Buku Panduan Praktis Pelayanan Kontrasepsi, YBP-SP, Jakarta. 2014

UNESCAP. Maternal and Reproductive Health. 2011. [Artikel Internet]. Tersedia dari http://www.unescap.org/stat/data/syb2011/1-people/ Maternal-and-reproductive-health Dalam : Statistical Yearbook for Asia and the Pacific. Diakses tanggal 3 November 2017

Wulandari, Irma. Pengaruh Konseling Kontrasepsi Berencana (KB) Terhadap Pengetahuan dan Sikap Pasangan Usia Subur Dalam Menggunakan Kontrasepsi Jangka Panjang di Desa Suka Maju Kecamatan Sunggal Kabupaten Deli Serdang. 2016. Tesis. Universitas Sumatera Utara

Yunita Wulandari. Faktor-Faktor Yang Mempengaruhi Penggunaan Metode Kontrasepsi Jangka Panjang (MKJP) Pada Pasangan Usia Subur di Kabupaten Sambas. 2015. [Jurnal Internet. Tersedia dari repository.unmuhpnk.ac.id/314/1/

Naskah\%20Publikasi\%20new.pdf. Diakses tanggal 21 Oktober 2017 